\title{
Sustaining Cultural Heritage by Means of Museums in an Ever-Changing World
}

\author{
Değişen Dünyada Kültürel Mirası Müzelerin Yardımıyla Sürdürmek \\ Ferika ÖZER SARI* \\ Murat NAZLI***
}

\begin{abstract}
The main objective of this comparative study is to understand and analyse the sustainability perspectives of museums in France, Canada, Sweden, Turkey and Greece. By adopting a qualitative research approach, data were gathered from eleven museum officials in five different countries. As an interesting result of the study, an advanced use of technology was seen at the oldest museum of the research sample. Overall, the comparative analysis revealed that general sustainability efforts, use of technology in presenting cultural heritage and active participation of visitors to the museum activities need to be improved and paid more attention at some of the museums. The increase in the number of museum activities contributes to the understanding of how cultural heritage can be sustained. The study sheds a light on the inside of changing museology and offers suggestions to the researchers in this field.
\end{abstract}

Keywords: Museum Management, Change, Sustainability, Culture, Heritage.

Öz

Çalışmanın temel amacı, Yunanistan, Türkiye, İsveç, Kanada ve Fransa'daki müzelerin sürdürülebilirlik kavramına bakış açılarını anlamak ve analiz etmektir. Niteliksel araştırma yöntemleri kullanılmış, 5 farklı ülkede 11 müze yetkilisi ile derinlemesine görüşmeler yapılarak veriler toplanmıştır. Çalışmanın ilginç bir sonucu olarak, araştırma örneklemindeki en eski müzede, ileri teknoloji kullanımı görülmüştür. Karşılaştırmalı analizlerin ortaya çıkardığı sonuçlara göre; müze faaliyetlerine ziyaretçilerin aktif katılımının, kültürel mirası sunarken teknoloji kullanımının ve genel sürdürülebilirlik çabalarının geliştirilmesi ve bazı müzelerde daha dikkatle ele alınması gerekmektedir. Müze etkinliklerinin sayısındaki artışın, kültürel mirasın nasıl sürdürüleceğinin anlaşılmasına katkısı olmaktadır. Çalışmada, değişen müzeciliğin içyüzüne 1şık tutulmaya çalışılmakta, alandaki araştırmacılara önerilerde bulunulmaktadır.

Anahtar Kelimeler: Müze yönetimi, değişim, sürdürülebilirlik, kültür, miras

\section{Introduction}

Today, along with the influence of globalization, advances in information technology (Joo et al., 2009), changes in expectations in the societies and organizations, our perception of cultural heritage is altering through the lens of an interactive era (Bowers, 2016). Our perception must now be redefined in the changing global cultural commons. To understand what is happening, many people are looking toward the sites where culture and history come together - that is, toward cultural heritage. The sustainability of cultural heritage is also in the process, flowing with the tide and it presents itself in several ways.

Heritage sites and museums have had to come across with the challenge of being open to entrepreneurial perspectives while meeting their heritage preservation and education activities (Silberberg, 1994). There is currently a huge debate on the scope and practice of museums in the $21^{\text {st }}$ century (Alcaraz et al., 2009). Museums play an essential role in comprehending the sustainability of cultural heritage, preserving the heritage and presenting it to the next generations (Del Barrio et al., 2009). What they bring to the community, how they sustain their development and operate their practices is a worthwhile topic to discuss today.

The huge amount of present cultural heritage material, which surpasses the available space in museums, and the rising attention in making collections accessible to the public have motivated cultural heritage organizations to adjust mobile information and web-based

\footnotetext{
* Yrd. Doç.Dr. Yaşar Üniversitesi, Uygulamalı Bilimler Yüksek Okulu, Gastronomi ve Mutfak Sanatları Bölümü, ferika.ozersari@yasar.edu.tr.

,** Dr. nazli.murat@gmail.com.
}

Özer Sarı, F., Nazlı M., (2018). Sustaining Cultural Heritage by Means of Museums in an Ever-Changing World, Gaziantep University Journal of Social Sciences, 17 (1), 1-14, DOI: 10.21547/jss.316178, Submission Date: 2605-2017, Acceptance Date: 07-09-2017.

Araştırma Makalesi. 
applications for exhibiting their collections. Most organizations are developing web sites so as to achieve a low-cost web existence and providing mobile guides to aid visitors on site (Ardissono et al., 2012). In fact, these types of technological developments brought various perspectives to the museums in terms of sustaining the cultural heritage.

Despite all the efforts, the matter of the cultural heritage has deteriorated during recent years as a consequence of industrialization, fast urbanization, rise in environmental pollution, several climatic changes and mass tourism. Additionally, several instances of the non-physical heritage are becoming extinct due to the paralysation of economic structures and fast alterations in life-styles (Jokilehto, 2005; UNESCO, 1989). However, a concentrated effort to protect cultural heritage is crucial to community's culture, educational activities, perception of heritage values and sustainable development.

This study first reviews the concept of cultural heritage and then the relationship between sustainability of cultural heritage and changing museology. The third section on methodology describes the research question, purpose of the study, sample and methods. Next, findings of the study are discussed in terms of interview results related to the establishment dates, primary purpose and visitor numbers, preservation and sustainability efforts and active participation of visitors. The study concludes with the limitations of study and recommendations for future research subsequent to the conclusion and implications section.

\section{Cultural Heritage Concept}

The term 'cultural heritage' includes various principal categories of heritage and heritage is presented by UNESCO (2016) as cultural heritage, natural heritage and heritage related with military. Cultural heritage: Tangible cultural heritage (paintings, sculptures, coins; immovable such as archaeological sites, monuments and underwater such as shipwrecks, underwater remnants) and Intangible cultural heritage (oral traditions, rituals, performing arts). Natural heritage: Natural areas with cultural aspects such as cultural landscapes, physical, biological formations. Heritage related with military.

Cultural heritage is any aspect of a society's past and present that it holds to be significant and aspires to pass on to future generations. It is many times described as objects, places or practices which have been a time-honoured tradition or which have a connection to history. It isn't always about previous matters. New or recently changed, objects, areas and practices can hold cultural value for current generations and have the potential to become constituents of cultural heritage (Rio Tinto, 2011). With reference to UNESCO (1989), cultural heritage is described as the total corpus of material signs - symbolic or artistic - passed on by the past to every culture and thus, to the whole of humankind. As a component of the affirmation and enrichment of cultural identities as a legacy belonging to humanity, the cultural heritage provides each specific place its distinguishable features and is a valuable resource of human experience. The protection and exhibition of cultural heritage is thus a foundation of any cultural policy. Moreover, as Endresen (1999), Del Barrio et al. (2009) and Mortara et al. (2014) emphasized that there are various reasons for public and private sector inclusion in management of cultural heritage, containing; the confirmation that heritage resources can play an essential role in community continuity, regeneration and progress, the rising quality of life associated with heritage resources, the heritage resources in creating and preserving personal and community identity, the worth of heritage resources in the education of kids through historical videogames and virtual museum activities and the part that heritage resources can play in assuring for recreation/pleasure occasions.

Along with the management of cultural heritage, custodians play a pivotal role in sustaining the heritage places and rather than short-term views, make long-term connections with the sites. Chirikure and Pwiti (2008, p. 480) stated that cultural heritage is formed and 
owned by the human beings, however one should realize the protectors related with historical sites. Traditional keepers: Having a straight linkage with the site, whose traditional rules have all times preserved heritage sites. Local keepers: Not having direct connection with the place but staying close to it. Professional keepers: Organizations empowered by authorities to manage heritage sites.

By this way, these traditional, local and professional custodians might help improve sustainable perspectives of the organizations and authorities. Considering changing museums in the new era together with the usage of these connections, Gilmore and Rentschler (2002) emphasized that comprehending the keeper's role and the requirement to allure more visitors is crucial. Concordantly, cultural heritage may keep alive and allure more visitors by implementation of a sustainable tourism development policy (Forga \& Valiente, 2015) as well as a balanced and controlled change in the management perspectives of those organisations that represent culture such as museums.

\section{Sustainability of Cultural Heritage and Changing Museums}

The Brundtland Report which is the outcome of the work done in 1987 by the World Commission on Environment and Development, presented the concept of sustainability including economic, social and environmental perspectives. The report's sustainability definition is 'Sustainable development is the development that provides the needs of the present without compromising the capability of future generations to meet their own needs.' (Brundtland Report, 1987; WTO, 1998; PricewaterhouseCoopers, 2012).

Cultural heritage includes all contemporary demonstrations when intangible and past proofs in the case of tangible artefacts of human creative effort that are handed down from past generations and taken into consideration by communities and thus preserved in the present and passed on to the future generations. Cultural heritage is essential as a resource of memory and inspiration while it conduces to local and national community identity which is essential for sense of place and social cohesion (Communities \& Local Government, 2009). That is why sustainability of cultural heritage is essential to the survival of that identity, memory, social and inspirational factors. Accordingly, museums have a major role in understanding the sustainability of cultural heritage, preserving and presenting it to future generations. There is a current discussion on the scope and practice of museums in the $21^{\text {st }}$ century (Alcaraz, 2009). It is essential for the museums to be sustainable organizations because they are considered to be a part of creating and preserving a sustainable community on the local and international arena (WGMSC, 2007). It is partly through their protection of collections and also through the provision of resources to the community that museums be a 'powerful means of achieving cultural, environmental, financial and social sustainability' (Birtley, 2006). Additionally, according to Silberberg (1994), museums and heritage sites have had to come across with the challenge of being open to entrepreneurial activities while continuing to preserve their heritage and meet educational activities for the visitors.

Traditionally, the main function of the museums has been to collect, maintain and study objects and pieces. The director was seen as the keeper of them who mainly performed the custodial role for the cultural capital of the organization: its creative works. Today, managing museums entails comprehending both the custodial part and the necessity to attract more visitors (Gilmore \& Rentschler, 2002). Their above mentioned function seems to be changing as their range, reason for being, content and their target audience differentiates due to the fact that local and global trends are changing. Nowadays, museums look more people oriented, act more towards education and leisure and encourage visitors to participate in museum processes and functions (Pirnar \& Sari, 2013). 
According to Visser (2014), in the first decades of the $21^{\text {st }}$ century, the organizations that survived the $20^{\text {th }}$ century are facing new obstacles. Technological changes combined with the social changes that go along with them - altering education needs, career paths, social forms - menace the presence of those organizations that are very conservative. Organizations that equalise both stability and change can achieve a 'sustainable' precedence toward other organizations which could not be able to manage this process successfully (Burchell \& Kolb, 2006). Museums and other organizations that represent culture, heritage and art are not excluded from this movement. They are actually at the very heart of it. From this point of view, we may say that museums need to manage a certain degree of change in order to sustain cultural heritage and to pass it on to the next generations. Most of the time, change refers to technological improvement but obviously that's not all. In his study, Visser (2014) claimed that there are some challenges that museums can come across in a close future as following: Technology, broader concept of value, active participating communities and social institutions.

Technology: Technological changes combined with social changes threaten the presence of the organizations that are very conservative. Use of technology, understanding social media and adaptation (Fu et al., 2015, p. 286) is critical.

Broader concept of value: Many organizations - containing museums - have a narrow concept of value like money or profit. Museums and other organizations hardly do anything about it. Value has many features such as financial, political, social, emotional, creative, and educational. Realizing these values will help museums add to society.

Active participating communities: Engagement, digitally or otherwise, is essential in the improvement of a relation between people and organizations. If museums don't activate their audience or potential visitors once every while, they will lose them to rivals who provide the opportunity to participate.

Social institutions: A social institution structurally engages its stakeholder to create value. Museums will become social institutions as the years go by or they will become extinct. However, as Sandell (2003) stated that museums in some regions are improving their societarian aim and establishing associations with welfare, health and other entities and looking for delivering social outcomes.

When the subject is change, it will be useful to mention about Lewin's three phase model of organizational change through which they'll pass unfreezing, changing and refreezing phases (Vasile, 2014). However, the use of this approach was criticized for popularising the complexity of organizational change (Sandell, 2003; Kanter et al., 1992). It is mentioned by management theorists to support perspectives to change. This model provides a basis for comprehending the processes involved in repositioning the museum industry (Sandell, 2003). The unfreezing process includes creating a foundation and willingness to welcome change. Nadler (1993) emphasizes that the primary phase is to define and reveal displeasure with the present situation. By this way, resistance to change can be decreased by identifying insufficiencies of working practices. It is probable to describe the components of this phase within the museum industry currently. Livvarçin and Kurt (2012, p. 277) states that this can be done through informing human resources and showing conflicts, by this way an intentness to change can be fostered. A study, defining the potential for museums to behave as an intermediary of social inclusiveness (GLLAM, 2000) can work as a comparison against which museums can measure their performance and evaluate their museum practices. The second phase is changing which is inclining towards a new behaviour pattern and within organizational theory, includes long-term perspectives that will assist to take an organization away from its present place to its preferred position by adapting change (Livvarçin \& Kurt, 2012, p. 278). This basis of managing organizational change, when practiced in the museum industry, recommends the need for a 
holistic perspective with strategies that can encourage sustainable efforts. The last phase is refreezing which involves stabilizing changes or embracing a new behaviour. If individuals embrace a new behaviour, change will protect its permanency until the next planned change (Kritsonis, 2005). From an industry perspective, established structures to create and preserve standards in museum operations must be reassessed so as to support change, raise awareness of the social role of museums outside and within the industry.

The implementation of Lewin's model of change to the museum industry underlines the foundations which should support trials to build change in the industry and the industry can move towards a frame for designating the mechanisms which are likely to start and sustain the necessary alterations in business applications.

\section{Methodology}

\section{Research Question and Purpose of the Study}

Having a question like 'What is the perspective of various museums in the world in terms of presenting their activities, sustaining and protecting their cultural heritage?' in our mind, the main purpose of this study was to understand and analyse museums' sustainability perspectives and efforts in different regions of the world. The secondary aim of the study was to reveal the current situation of selected museums in terms of technology use and active participation of guests.

\section{Sample}

The research data were basically gathered from 11 randomly selected museums (see Appendix) from 5 different countries as France, Canada, Sweden, Turkey and Greece in 7 months, starting from mid-2015 (from late February to late September). These museums were chosen to give a range of subjects, sizes and various types of activities taking place in recent years. The selected museums including their countries and regions are presented in tables.

\section{Method}

Fundamentally, a face to face semi-structured interview method with open-ended questions is preferred in this exploratory research. In order to make in-depth analysis of sustainability perspectives, main purposes and activities by the museum officials, four fundamental questions including three sub-questions were asked to eleven museum officials or responsible managers. Interviews took approximately 50 minutes to get the necessary responses. A total of four questions are asked to 11 museum officials which consist of two Director of Museum Operations, one Interim President and eight Operations Supervisors. All of the 11 respondents requested that their names are kept confidential. The first three questions are related with their establishment date, fundamental purposes, activity areas, number of yearly visitors and visit fees. The last question is about the sustainability of the museums, how they approach to the subject of protecting, presenting and sustaining the cultural heritage and how they approach to the active participation of visitors in the museum.

\section{Findings}

As a result of the interviews and observations at eleven museums in five countries, the findings that are obtained are presented thoroughly within the scope of their establishment dates (Table 1), primary purpose and general activities, number of visitors and entrance fees, their way of preserving heritage and sustainability efforts (Table 2) and active participation of visitors in the museum activities (Table 3 ). 


\section{Establishment Dates, Primary Purpose}

M1 in Canada is established in 1932 (Table1) which is the oldest museum among the researched ones. The second oldest one is the M2 in Sweden with the date of 1953. The newest one is M11 in Canada which is established in 2008. The second newest one is M10 in Turkey which opened its doors in 2002.

Table 1: Establishment dates of the museums

\begin{tabular}{|l|c|l|c|}
\hline \multicolumn{1}{|c|}{ Country- Museum } & Date of establishment & \multicolumn{1}{c|}{ Country- Museum } & $\begin{array}{c}\text { Date of } \\
\text { establishment }\end{array}$ \\
\hline Canada - M1 & 1932 & Turkey - M7 & 1994 \\
\hline Sweden -M2 & 1953 & Greece - M8 & 1999 \\
\hline France - M3 & 1957 & Sweden -M9 & 2001 \\
\hline Greece - M4 & 1974 & Turkey - M10 & 2002 \\
\hline Greece - M5 & 1980 & Canada - M11 & 2008 \\
\hline Sweden -M6 & 1990 & \multicolumn{2}{|c|}{} \\
\hline
\end{tabular}

The researched museums have various purposes and activities. M1 offers a living history of man and his environment. With programs such as museum sleepovers and day camps, the aim is to educate kids with the history of man in that region and power of nature demonstrated by the science museum. 178 events took place in the last year and the museum facilitated 85.000 students to learn about human and natural history of the region, astronomy and science through at least 70 programs. M11's aim is to create a national and international destination of learning where Canadians and international people can engage in discussion and commit to taking action against hate and racism crimes. Maintaining and promoting heritage at home and overseas, investing in collective memory and identity of Canadians, inspiring learning, research and entertainment are key in their purpose and activities. M3-France aims to be a cultural, historical and touristic major leader, at a local and regional level. M8-Greece presents the island's prehistoric settlements, sculptures, inscriptions, coins, pottery collection and sanctuaries. M4 in Greece aims to be a place of knowledge, to open up the public to the folklore heritage of the island. M5's objective in Greece is the conservation of buildings while respecting its character as well as its transformation into a museum. M2's purpose in Sweden is to explain the history of dance with audio-visuals, costumes, books, largest selection of dance DVDs. M9 in Sweden tells stories of world- renowned 'Prizes' and famous people with supporting events, visuals, etc. Purpose of M6 in Sweden is to preserve the survival of the $98 \%$ protected ship by watering wooden parts regularly for not letting it rotten and presenting it worldwide. There are activities like film auditorium, a model of the ship for visually impaired visitors, guided tours, etc. M7 in Turkey is dedicated to research, collection, protection, and exhibition of documents, objects related with industries and engineering from several countries and eras. Purpose is to spread museum visits in Turkey and support continuous research for the industrial history. M10 in Turkey also offers a sophisticated museological taste with its affluent permanent collection, comprehensive exhibitions that it hosts its conservation units, education programs and concerts.

There are various entrance fees between $1 €-14 €$ range except the free entrances. Among the eleven museums, M6 in Sweden pulled much more visitors which are 1.2 million in 2014. The second is M1 (Canada) which had 374.961 visitors.

\section{Preservation and Sustainability Efforts}

In protecting and sustaining cultural heritage (Table 2), museums play a significant role. In M1, cultural preservation has been taken underway by teams that have taken at least 700 oral interviews. The museum's Oral History Collection is a rich resource that contains voices of locals since the 1970s. M11 protecting and sustaining cultural heritage through creating awareness of human rights issues, understanding past struggles of the ancestors of Canadians. M3-France tries to preserve cultural heritage sustainably, exhibit, welcome, communicate, 
renovate and develop cultural activities. The interviewees in M8-Greece mentioned that they protect and sustain cultural heritage through security guards, cameras and police officers. The approach in M4 is that Greek culture and history (language, literature, folklore, art) as a whole considered as cultural heritage and it is not possible for the Greek state to find ways to protect it all. For preserving and sustaining heritage, government employs many people. In M5-Greece, the aim is to conserve the building while respecting its character as a monument as well as its transformation into a museum. In M2-Sweden, the purpose is to explain the history of dance. The museum has the world's $2^{\text {nd }}$ largest collection of costumes from the legendary Ballets Russes of Paris between the years 1909 and 1929. In M9-Sweden, there are various activities and donations to help museum sustain the heritage. For M7-Turkey, education (primary school, kinder garden education projects, science and technology workshops, weekend workshops for technical schools and museum bus for underprivileged children) is critical for its sustainability. Similarly, in M10-Turkey, educational activities, get-acquainted tours, workshops, guided tours of exhibitions, adult workshops and others (activities for children, adults, students, yoga classes and social responsibility projects) take place.

Table 2: Protecting and sustaining cultural heritage

\begin{tabular}{|c|c|}
\hline $\begin{array}{l}\text { Name of the } \\
\text { museum }\end{array}$ & Protecting and sustaining cultural heritage \\
\hline M1 & $\begin{array}{l}\text { Cultural preservation has been taken underway by teams that have taken } 700 \\
\text { interviews. The museum's Oral History Collection is a rich resource that contains } \\
\text { voices of Manitobans since the 1970s. }\end{array}$ \\
\hline Sweden - M2 & $\begin{array}{l}\text { To explain the history of dance. It has the world's } 2^{\text {nd }} \text { largest collection of costumes } \\
\text { from the Russian Ballet in Paris for } 20 \text { years (1909-1929). }\end{array}$ \\
\hline France - M3 & $\begin{array}{l}\text { To preserve sustainably, to exhibit, welcome, communicate, renovate, develop cultural } \\
\text { activities (visits, activities for youngsters). }\end{array}$ \\
\hline Greec & $\begin{array}{l}\text { Greek culture and history (language, literature, folklore, art) as a whole considered as } \\
\text { cultural heritage, Many people are employed to preserve exhibits in Greece. }\end{array}$ \\
\hline Greece - M5 & $\begin{array}{l}\text { To conserve the building while respecting its character as a monument as well as its } \\
\text { transformation into a museum. }\end{array}$ \\
\hline Sweden - M6 & $\begin{array}{l}\text { Preservation of a war ship by using several techniques such as watering wooden parts } \\
\text { and fixing regularly for not letting it rotten. }\end{array}$ \\
\hline Turkey - M7 & $\begin{array}{l}\text { Museum education (primary school, kinder garden projects, science, technology } \\
\text { workshops, weekend workshops for technical schools, museum bus for underprivileged } \\
\text { children. }\end{array}$ \\
\hline Greece - M8 & $\begin{array}{l}\text { Security guards, cameras, close circuit camera, police officers, like banks, press the } \\
\text { button and police arrives in } 2 \text { minutes. }\end{array}$ \\
\hline Sweden - M9 & Activities, donations help sustain the heritage. \\
\hline Turkey - M10 & $\begin{array}{l}\text { Educational activities, get-acquainted \& school exhibition tours, workshops, guided } \\
\text { tours of exhibitions, adult workshops, others (activities for children, adults, students, } \\
\text { yoga classes, social responsibility projects). }\end{array}$ \\
\hline Canada - M11 & $\begin{array}{l}\text { Through awareness of human's rights issues, Canadians can be more cognitive towards } \\
\text { past struggles of their ancestors across the world. Focus is the Holocaust exhibit that } \\
\text { educates \& gives respect to victims of war crime. }\end{array}$ \\
\hline
\end{tabular}




\section{Active Participation of Visitors}

In M1, visitors have hands on interpretive experience with artefacts learning and engaging with history and science (Table 3 ). Families are encouraged to come there for a quality family experience. M11 as part of the content development process did a cross-country tour from May 2009 to February 2010, where they talked to thousands of people about their human rights experiences and what they would like to see in the museum. Visitors are given an interactive presentation and multimedia technology is used along with a world-class design. Not very detailed information about active participation of visitors is given by M3 of France and M8 of Greece. However, M4 in Greece emphasized that active participation of visitors is encouraged and their goal is to further their knowledge of the history and culture of a civilization. M5 has four sections and every section is supported with commentary and printed material of general and specialized content, all exhibits have bilingual legends. Visitors can move within the exhibition following a path and wander freely. The exhibition plays an educational role, by presenting the island's rich history, stimulating the visitor to delve into thematic unities of exhibition. The Mosque and exhibition co-exist harmonically and complement each other.

In M2-Sweden (Table 3), dance performances, workshops, dancing activities for children and grown-ups take place. You can watch both dance and art and even dance yourself. There are tours for visually impaired, play rooms for kids and touchable tablets. In M9-Sweden, guests participate in activities such as guided tours, seminars and school activities for children. The ones who won the international 'Prize' usually donate at least one artefact to museum's collectives and contribute with their signatures. Interactive screens, films on ground, headphones and several languages are available. In M6-Sweden, part of real deck was imitated and there are waxed people with costumes to make you feel that you are inside the ship and there are computers loading and sailing a $17^{\text {th }}$ century ship. M7-Turkey offers activities for the teachers and students, rentals such as corporate events, birthdays, professional shootings (wedding photography catalogues). At M10-Turkey there is an educational part for children and adults. Youngsters get to know the artists, learn how to observe, interpret their works, deeply think of works and intensify what they have learned in the atelier.

Table 3: The situation of visitors' active participation

\begin{tabular}{|c|c|}
\hline $\begin{array}{l}\text { Name of the } \\
\text { museum }\end{array}$ & Active participation of visitors \\
\hline Canada - M1 & $\begin{array}{l}\text { Having hands on interpretive experience with artefacts, learning \& engaging with } \\
\text { history \& science. Families encouraged coming for a quality family experience. }\end{array}$ \\
\hline Sweden - M2 & $\begin{array}{l}\text { Performing dance performances, workshops, dancing activities for children \& grown- } \\
\text { ups, non-stop screenings, you can watch both dance and art even dance yourself. Tours } \\
\text { for visually impaired, play rooms for kids, you pull the drawer, music comes out, } \\
\text { touchable tablets. }\end{array}$ \\
\hline France - M3 & Cultural activities for youngsters. \\
\hline Greece - M4 & $\begin{array}{l}\text { Active participation of visitors is encouraged to further their knowledge of the history } \\
\text { and culture of a civilization. }\end{array}$ \\
\hline Greece - M5 & $\begin{array}{l}\text { Sections are supported with commentary, printed material of general content. The } \\
\text { exhibition plays an educational role, by presenting island's history, stimulating the } \\
\text { visitor to delve into thematic unities of exhibition. }\end{array}$ \\
\hline
\end{tabular}




\begin{tabular}{|l|l|}
\hline Sweden - M6 & $\begin{array}{l}\text { Part of real deck was imitated to make you feel that you are inside the ship, waxed } \\
\text { people with costumes, loading \& sailing a } 17^{\text {th }} \text { century ship by computer. }\end{array}$ \\
\hline Turkey - M7 & $\begin{array}{l}\text { Stated above (activities for teachers, students), rentals such as corporate events, } \\
\text { birthdays, professional shootings (wedding photography, catalogues, commercial). }\end{array}$ \\
\hline Greece - M8 & For students and elderly people 1 or 2 times a year. \\
\hline Sweden - M9 & $\begin{array}{l}\text { Guided tours, seminars, school activities. The ones who won the 'N' prize usually } \\
\text { donate at least one artefact to museum's collectives, contribute with their signatures. } \\
\text { Interactive screens, films played on ground, headphones, several languages available. }\end{array}$ \\
\hline Turkey - M10 & $\begin{array}{l}\text { Stated above (educational part for children, students, adults). Youngsters get to know } \\
\text { artists, learn how to observe \& interpret their works, think about them, intensify what } \\
\text { they have learned in the studio. }\end{array}$ \\
\hline Canada - M11 & $\begin{array}{l}\text { As part of the content development process, M11 did a cross-country tour between } \\
\text { 2009-2010, talked to thousands of people about their human rights experiences \& what } \\
\text { they want to see in the museum. }\end{array}$ \\
\hline
\end{tabular}

\section{Overall Picture of the Findings}

In terms of evaluation of the findings, the establishment date of museums varies. The oldest one is M1 established in 1932. In considering their primary aim and general activities, each museum has a unique approach in sustaining heritage and shows various sustainability efforts and wide range of interests for their survival. Each museum has a unique history and background, is willing to host as many visitors as it can by informing the community due to various activities. Yearly number of visitors is available in only seven museums where the other four museums lack the statistical information. The entrance fees vary depending on occupation, age, student or citizen, disabled, military personnel etc.

Furthermore, in preserving and sustaining culture, each museum has its own way of looking at sustainability and protection of cultural heritage, depending on their purposes and activities. The use of technology has more impact in museums in Sweden than those of others. A variety of preservation methods take place in the researched museums such as; renovations, security guards, donations, government support, developing cultural activities, oral records, photography and social responsibility projects.

In active participation of the visitors, several activities are offered by the museums such as; educational activities for different ages, corporate events, interactive presentations, play rooms for kids, support of technology, live performances, guided tours, seminars, playing in the imitated deck, photo shootings and events for disabled visitors.

\section{Conclusion and Implications}

As a result of the comparative analysis of eleven museums in five different countries, Table 4 is generated. It basically represents the analysis and evaluations on the basis of technology use, general sustainability efforts, protecting and sustaining cultural heritage and level of active participation of visitors.

Table 4: Comparisons between researched museums

\begin{tabular}{|l|c|c|c|}
\hline \multirow{2}{*}{ Country- Museum- Date } & \multicolumn{2}{|c|}{ Technology Use } & \\
\cline { 2 - 4 } & In need of improvement & Progressing & Advanced \\
\hline Canada - M1 - 1932 & & $\sqrt{ }$ & $\sqrt{ }$ \\
\hline Sweden - M2 - 1953 & & $\sqrt{ }$ \\
\hline
\end{tabular}




\begin{tabular}{|c|c|c|c|}
\hline France - M3 - 1957 & & $\sqrt{ }$ & \\
\hline Greece - M4 - 1974 & $\sqrt{ }$ & & \\
\hline Greece - M5 - 1980 & $\sqrt{ }$ & & \\
\hline Sweden - M6 - 1990 & & & $\sqrt{ }$ \\
\hline Turkey - M7 - 1994 & & $\sqrt{ }$ & \\
\hline Greece - M8 - 1999 & $\sqrt{ }$ & & \\
\hline Sweden - M9 - 2001 & & & $\sqrt{ }$ \\
\hline Turkey - M10-2002 & & $\sqrt{ }$ & \\
\hline Canada - M11-2008 & & & $\sqrt{ }$ \\
\hline \multirow{2}{*}{ Country-Museum- Date } & \multicolumn{3}{|c|}{ General Sustainability Efforts } \\
\hline & In need of improvement & Progressing & Advanced \\
\hline Canada - M1 - 1932 & & & $\sqrt{ }$ \\
\hline Sweden - M2 - 1953 & & $\sqrt{ }$ & \\
\hline France - M3 - 1957 & & $\sqrt{ }$ & \\
\hline Greece - M4 - 1974 & & $\sqrt{ }$ & \\
\hline Greece - M5 - 1980 & & $\sqrt{ }$ & \\
\hline Sweden - M6 - 1990 & & & $\sqrt{ }$ \\
\hline Turkey - M7 - 1994 & & & $\sqrt{ }$ \\
\hline Greece - M8 - 1999 & $\sqrt{ }$ & & \\
\hline Sweden - M9 - 2001 & & & $\sqrt{ }$ \\
\hline Turkey - M10-2002 & & & $\sqrt{ }$ \\
\hline Canada - M11- 2008 & & & $\sqrt{ }$ \\
\hline \multirow{2}{*}{ Country- Museum- Date } & \multicolumn{3}{|c|}{ Protecting \& Sustaining Heritage } \\
\hline & In need of improvement & Progressing & Advanced \\
\hline Canada - M1 - 1932 & & & $\sqrt{ }$ \\
\hline Sweden - M2 - 1953 & & $\sqrt{ }$ & \\
\hline France - M3 - 1957 & & & $\sqrt{ }$ \\
\hline Greece - M4 - 1974 & & $\sqrt{ }$ & \\
\hline Greece - M5 - 1980 & & $\sqrt{ }$ & \\
\hline Sweden - M6 - 1990 & & & $\sqrt{ }$ \\
\hline Turkey - M7 - 1994 & & & $\sqrt{ }$ \\
\hline Greece - M8 - 1999 & & $\sqrt{ }$ & \\
\hline Sweden - M9 - 2001 & & & $\sqrt{ }$ \\
\hline Turkey - M10-2002 & & & $\sqrt{ }$ \\
\hline Canada - M11- 2008 & & & $\sqrt{ }$ \\
\hline \multirow{2}{*}{ Country-Museum- Date } & \multicolumn{3}{|c|}{ Active Participation Of Visitors } \\
\hline & In need of improvement & Progressing & Advanced \\
\hline Canada - M1 - 1932 & & $\sqrt{ }$ & \\
\hline Sweden - M2 - 1953 & & & $\sqrt{ }$ \\
\hline France - M3 - 1957 & $\sqrt{ }$ & & \\
\hline Greece - M4 - 1974 & & $\sqrt{ }$ & \\
\hline Greece - M5 - 1980 & & $\sqrt{ }$ & \\
\hline Sweden - M6 - 1990 & & & $\sqrt{ }$ \\
\hline Turkey - M7 - 1994 & & & $\sqrt{ }$ \\
\hline Greece - M8 - 1999 & $\sqrt{ }$ & & \\
\hline Sweden - M9 - 2001 & & & $\sqrt{ }$ \\
\hline Turkey - M10-2002 & & & $\sqrt{ }$ \\
\hline Canada - M11- 2008 & & & $\sqrt{ }$ \\
\hline
\end{tabular}

Overall, comparative analysis revealed that general sustainability efforts, use of technology in presenting cultural heritage and active participation of visitors in museum activities need to be improved and paid careful attention at some of the museums (M3, M4, M5 and M8). However, we see an advanced usage of technology at the oldest museum (M1-Canada) which managed a certain degree of change in its 84 years of experience and existence. In 
preserving and sustaining cultural heritage, each museum has its own approach and they are in the scale of 'progressing' and 'advanced'. In addition, the increased various number of museum activities stimulate the sustainability perspectives of the researched museums. The heritage resources play an essential role in the education of children in most of the museums which provide pleasure/recreation opportunities. Specifically, the level of technology and its use in the researched museums in Sweden and Canada is advanced as compared to others.

However, the influence of technology use, visual and technological advances on cultural heritage (Styliani et al., 2009; Mortara et al., 2014) is profound and pervasive. From the changeoriented perspective of today, museums are reliant on updated technology to manage their collections. They collect digital as well as material objects. New media is embedded within their exhibition spaces (Parry, 2013; Fu et al., 2015). Along with the use of technology, value additions to the museums, participative communities and specifically recognition of trends to the society's advantage, the way forward is to become more social institutions (Visser, 2014; ICOM, 2012) and also to create more engaged and satisfied visitors (Trinh \& Ryan, 2013, p. 242).

From the museum industry stand point, the established structures to create and preserve the main standards in museum operations must be re-evaluated so as to support change (Forga \& Valiente, 2015, p. 4) and all these efforts will serve to raise great awareness of the social role and contribution of museums in the industry. In this sense, according to Domic and Boukas (2015, p. 17) what is essential is that policies should be initiated that would incorporate the perspectives of the audiences as a pivotal part of the museum's progress. Regarding the application of Lewin's model of change to the museum industry, the approach underlines the principles which should support attempts to create industry-wide change. Along with this way, the industry can move towards a frame for identifying the mechanisms which are likely to start and sustain the necessary alterations in working practices.

In developed countries, perspectives for tourism development planning have moved from a traditional, narrow consideration of supply, demand and physical necessities to more integrated, comprehensive and environmentally conscious views for sustainable tourism development (Tosun, 2000; Bowers, 2016), through the communication of sustainable practices (Wickham \& Lehman, 2015). This sensitivity and level of awareness about sustainability is actually seen in various dimensions in the researched museums. Sustainability is becoming a larger part of business life and leaders, policy makers, investors and other stakeholders are paying attention to sustainability efforts. Correspondingly, this qualitative study shows that some museums are searching for various ways to keep up with the changing trends, improve their physical, technological and operational structure and sustain their cultural heritage in a meticulous way. Additionally, the research gives museum authorities a clue on how to protect and sustain cultural heritage and notify them of sustainable practices by showing the perspectives of various museums from various regions of the world.

\section{Limitations and Future Research}

The research has some limitations. First of all, it is an exploratory analysis trying to analyse the sustainability efforts of museums in several countries. Within the bounds of possibility, only eleven museums could be selected from five different countries. As another limitation, the collection of data was difficult during the office hours of museum officials. For future research, within a specific region, city or country, museum perspectives can be gathered and made comparisons. A survey can be made to see what the organizations think crucial for their sustainability, what they consider noteworthy to measure in understanding sustainability. The survey, in review of existing government policies and regulations, can be useful for re- 
evaluating the current indicators, and also it can be used as a tool for consensus on sustainability matters between the museums.

\section{References}

Alcaraz, C., Hume, M., \& Mort, G. S. (2009). Creating sustainable practice in a museum context: Adopting service-centricity in non-profit museums. Australasian Marketing Journal (AMJ), 17(4), 219-225.

Ardissono, L., Kufik, T., \& Petrelli, D. (2012). Personalization in cultural heritage: the road travelled and the one ahead. User Modelling and User Adapted Interaction, 22(1-2), 73 99.

Birtley, M. (2006). The Collections Council of Australia paper prepared for the 2006 Australian State of the Environment Committee, Department of the Environment and Heritage, Canberra. Retrieved from http://www.deh.gov.au/soe/2006/emerging/collections/index.html

Bowers, J. (2016). Developing sustainable tourism through ecomuseology: a case study in the Rupununi region of Guyana. Journal of Sustainable Tourism, 24(5), 758-782. DOI:10.1080/09669582.2015.1085867.

Brundtland Report (1987). Report of the World Commission on Environment \&Development: Our Common Future. Retrieved from http:www.bneportal.de/fileadmin/unesco/de/Downloads/Hintergrundmaterial_internati onal/Brundtlandberich.File.pdf?linklisted $=2812$

Burchell, N., \& Kolb, D. (2006). Stability and change for sustainability. University of Aucland Business Review, 8(2), 32-41.

Chirikure, S., \& Pwiti, G. (2008). Community Involvement in Archaeology and Cultural Heritage Management. Current Anthropology, 49(3), 467-485.

Communities \& Local Government (2009). Draft Planning Policy Statement 15: Planning for the Historic Environment, Communities \& Local Government Publications, London. Retrieved

from http://webarchive.nationalarchives.gov.uk/20120919132719/http://www.communities. gov.uk/documents/planningandbuilding/pdf/consultationhistoricpps.pdf

Del Barrio, M. J., Herrero, L. C., \& Sanz, J. Á. (2009). Measuring the efficiency of heritage institutions: A case study of a regional system of museums in Spain. Journal of Cultural Heritage, 10(2), 258-268.

Domic, D., \& Boukas, N. (2015). Identifying Croatian museums' indigenous visitors in a postwar era: perceptual examinations of one's own heritage. Journal of Tourism and Cultural Change, DOI:10.1080/14766825.2015.1120308.

Endresen, K. (1999). Sustainable Tourism and Cultural Heritage. Report.

Forga, J. M. P., \& Valiente, G, C. (2015). Cultural change and industrial heritage tourism: material heritage of the industries of food and beverage in Catalonia (Spain). Journal of Tourism and Cultural Change, DOI:10.1080/14766825.2015.1108327.

Fu, Y., Kim, S., \& Zhou, T. (2015). Staging the 'authenticity' of intangible heritage from the production perspective: the case of craftsmanship museum cluster in Hangzhou, China. Journal of Tourism and Cultural Change, 13(4), 285-300.

Gilmore, A., \& Rentschler, R. (2002). Changes in museum management: A custodial or marketing emphasis? Journal of Management Development, 21(10), 745-760.

GLLAM Report (2000). Museums and Social Inclusion. Retrieved from https://www2.le.ac.uk/departments/museumstudies/rcmg/projects/museums-andsocial-inclusion-the-gllam-report/GLLAM\%20Interior.pdf

ICOM - International Council of Museums (2012). Museums in a Changing World. Retrieved from http://network.icom.museum/imd2012/imd-2012/museums-in-a- changing-world/ 
Jokilehto, J. (2005). Definition of Cultural Heritage - References to Documents in History. ICCROM Working Group 'Heritage and Society'.

Joo J., Yim J.\& Lee, C. (2009). Protecting cultural heritage tourism sites with the ubiquitous sensor network. Journal of Sustainable Tourism, 17(3), 397-406. DOI:10.1080/09669580802582498.

Kanter, R. M., Stein, A. B., \& Jick, D. T. (1992). The Challenge of Organizational Change. New York, Free Press.

Kritsonis, A. (2005). Comparison of Change Theories. International Journal of Management, Business, and Administration, 8(1), 1-7.

Livvarçin, O., \& Kurt, D. (2012). Yönetim Biliminde 49 İnsan 49 Teori. Beta Yayıncılık. 2. Bask1, Istanbul.

Mortara, M., Catalano, C. E., Bellotti, F., Fiucci, G., Houry-Panchetti, M., \& Petridis, P. (2014). Learning cultural heritage by serious games. Journal of Cultural Heritage, 15(3), 318325.

Nadler, D. A. (1993). Concepts for the Management of Organizational Change in Mabey, C. and Mayon-White, Bill (ed.) Managing Change, London: Paul Chapman Publishing.

Parry, R. (Ed.) (2013). Museums in a digital age. Routledge.

Pirnar, İ., \& Sari, F. Ö. (2013). The Changing Role of Museums: For Tourists or Local People?, International Conference on Sustainable Cultural Heritage Management, Collection of Abstracts, Roma Tre University, October 11-12 2013, Rome, Italy, pp. 45.

PricewaterhouseCoopers (2012). Türk İş Dünyası'nda Sürdürülebilirlik Uygulamaları Değerlendirme $\quad$ Raporu $2011 . \quad$ Retrieved from http://www.pwc.com.tr/tr/publications/arastirmalar/pdf/pwc_surdurulebilirlik_raporu2012.pdf

Rio Tinto (2011). Why Cultural Heritage Matters. Retrieved from http://www.riotinto.com/documents/ReportsPublications/Rio_Tinto_Cultural_Heritage _Guide.pdf

Sandell, R. (2003). Social inclusion, the museum and the dynamics of sectoral change. Museum and Society, 1(1), 45-62.

Silberberg, T. (1994). Cultural Tourism And Business Opportunities For Museums and Heritage Sites. Retrieved from http://www.sinolord.com/Media/Artcl_Ted_CultTourismBus Opps.pdf

Styliani, S., Fotis, L., Kostas, K., \& Petros, P. (2009). Virtual museums, a survey and some issues for consideration. Journal of Cultural Heritage, 10(4), 520-528.

Tosun, C. (2000). Challenges of sustainable tourism development in the developing world: the case of Turkey. Tourism Management, 22, 289-303.

Trinh, T. T., \& Ryan, C. (2013). Museums, exhibits and visitor satisfaction: a study of The Cham Museum, Danang, Vietnam. Journal of Tourism and Cultural Change, 11(4), 239-263, DOI: 10.1080/14766825.2013.829481.

UNESCO (1989). Medium Term Plan 1990 - 1995. Retrieved from http://unesdoc.unesco.org/images/0008/000825/082539eb.pdf

UNESCO (2016). What is meant by cultural heritage? Retrieved from http://www.unesco.org/new/en/culture/themes/illicit-trafficking-of-culturalproperty/unesco-database-of-national-cultural-heritage-laws/frequently-askedquestions/definition-of-the-culturalheritage/

WGMSC - Western Gas Measurement Short Course (2007). Museums and Sustainable Communities, Resource Document. Retrieved from http://worldviewsconsulting.org/uploads/3/1/1/2/3112423/wgmsc_resource_ document_307.pdf 
Wickham, M. \& Lehman, K. (2015). Communicating sustainability priorities in the Museum sector. Journal of Sustainable Tourism, 23(7), 1011-1028, DOI:10.1080/09669582.2015.1042483.

WTO - World Tourism Organization (1998). Guide for Local Authorities on Developing Sustainable Tourism. World Tourism Organization, Madrid.

Vasile, D. (2014). Copying With Organizational Change in the Tourism Industry. Cactus Tourism Journal, 10(2), 8-17.

Visser, J. (2014). Museums in times of social and technological change. Retrieved from http://themuseumofthefuture.com/2014/04/18/museums-in-times-of-social-\%20andtechnological-change/

Appendix

Identification of the research museums in alphabetical order according to country name

\begin{tabular}{|l|c|l|}
\hline \multicolumn{1}{|c|}{$\begin{array}{c}\text { Country (Alphabetical Order) And Name Of The } \\
\text { Museum }\end{array}$} & Establishment date & \multicolumn{1}{|c|}{ Public status } \\
\hline Canada - Museum of Man and Nature, Manitoba & 1932 & $\begin{array}{l}\text { Non-profit organization } \\
\text { incorporated by an act of the } \\
\text { Manitoba Legislature }\end{array}$ \\
\hline Canada- Canadian Human Rights Museum, Winnipeg & 2008 & Government \\
\hline France - National Navy Museum, Brest & 1957 & Government \\
\hline Greece - Archeological Museum of Chios & 1999 & Government \\
\hline Greece - Argentis Museum of Chios & 1974 & Government \\
\hline Greece - Byzantine Museum of Chios & 1980 & Government \\
\hline Sweden - Dance Museum Stockholm & 1953 & Private \\
\hline Sweden - Nobel Museum Stockholm & 2001 & $\begin{array}{l}\text { The Alfred Nobel Memorial } \\
\text { Foundation }\end{array}$ \\
\hline Sweden - Vasa Museum Stockholm & 1990 & Government \\
\hline Turkey - Rahmi M. Koç Museum Istanbul & 1994 & $\begin{array}{l}\text { Rahmi M. Koç Museology } \\
\text { and Culture Foundation }\end{array}$ \\
\hline Turkey - Sakıp Sabanci Museum Istanbul & 2002 & Sabanci University \\
\hline
\end{tabular}

